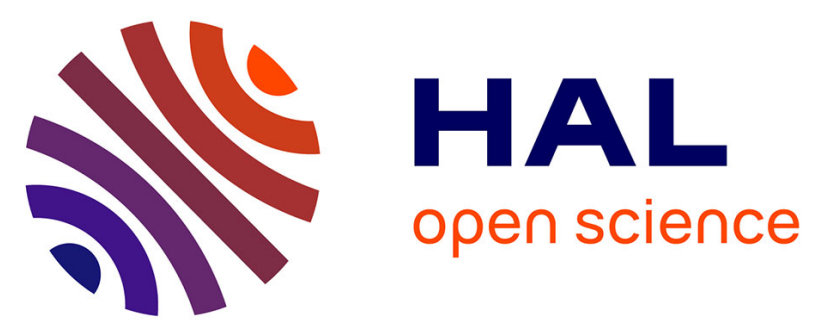

\title{
Validation of Tropospheric Water Vapor as Measured by the 183-GHz HAMSTRAD Radiometer Over the Pyrenees Mountains, France
}

P. Ricaud, Benjamin Gabard, Solène Derrien, Jean-Luc Attié, Thomas Rose, Harald Czekala

\section{To cite this version:}

P. Ricaud, Benjamin Gabard, Solène Derrien, Jean-Luc Attié, Thomas Rose, et al.. Validation of Tropospheric Water Vapor as Measured by the 183-GHz HAMSTRAD Radiometer Over the Pyrenees Mountains, France. IEEE Transactions on Geoscience and Remote Sensing, 2010, 48 (5), pp.21892203. 10.1109/TGRS.2009.2037920 . hal-00995287

\section{HAL Id: hal-00995287 \\ https://hal.science/hal-00995287}

Submitted on 10 Sep 2021

HAL is a multi-disciplinary open access archive for the deposit and dissemination of scientific research documents, whether they are published or not. The documents may come from teaching and research institutions in France or abroad, or from public or private research centers.
L'archive ouverte pluridisciplinaire HAL, est destinée au dépôt et à la diffusion de documents scientifiques de niveau recherche, publiés ou non, émanant des établissements d'enseignement et de recherche français ou étrangers, des laboratoires publics ou privés. 


\title{
Validation of Tropospheric Water Vapor as Measured by the 183-GHz HAMSTRAD Radiometer Over the Pyrenees Mountains, France
}

\author{
Philippe Ricaud, Benjamin Gabard, Solène Derrien, Jean-Luc Attié, Thomas Rose, and Harald Czekala
}

\begin{abstract}
The $\mathrm{H}_{2} \mathrm{O}$ Antarctica Microwave Stratospheric and Tropospheric Radiometers (HAMSTRAD) 183-GHz radiometer has been developed to measure vertical profiles of tropospheric water vapor above Dome C (Concordia station), Antarctica $\left(75^{\circ} 06^{\prime} \mathrm{S}, 123^{\circ} 21^{\prime} \mathrm{E}, 3233 \mathrm{~m}\right.$ asml $)$, which is an extremely cold and dry environment, over decades. Prior to its installation at Dome $\mathrm{C}$ in January 2009, the instrument was deployed at the Pic du Midi (PdM) station $\left(42^{\circ} 56^{\prime} \mathrm{N}, 0^{\circ} 08^{\prime} \mathrm{E}, 2877 \mathrm{~m}\right.$ asml) in the Pyrenees Mountains, France, over the period covering February-June 2008. Vertical profiles of absolute humidity and integrated water vapor (IWV) as measured by HAMSTRAD were compared with measurements from radiosondes launched in three different sites: Lannemezan $\left(43^{\circ} 07^{\prime} \mathrm{N}, 0^{\circ} 23^{\prime} \mathrm{E}, 610 \mathrm{~m}\right.$ asml), France ( $\sim 30 \mathrm{~km}$ northeast from PdM), Bordeaux-Mérignac Airport $\left(44^{\circ} 49^{\prime} \mathrm{N}, 0^{\circ} 42^{\prime} \mathrm{W}, 50 \mathrm{~m}\right.$ asml $)$, France $(\sim 220 \mathrm{~km}$ northwest from PdM), and Zaragoza $\left(41^{\circ} 39^{\prime} \mathrm{N}, 0^{\circ} 53^{\prime} \mathrm{W}, 263 \mathrm{~m}\right.$ asml), Spain $(\sim 170 \mathrm{~km}$ southwest from PdM). The validation process also used the vertical profiles of tropospheric $\mathrm{H}_{2} \mathrm{O}$ as measured by the nadir-viewing infrared atmospheric sounding interferometer (IASI) instrument aboard the MetOp-A space platform. The temporal evolution of the HAMSTRAD $\mathrm{H}_{2} \mathrm{O}$ measurements above the PdM station is very consistent with IASI, sonde, and in situ measurements, tracking the same atmosphere from a dry period in February to a wet period in June. HAMSTRAD showed unrealistic values in periods of well-established snow tempest. While the sensitivity of the HAMSTRAD measurements tends to be degraded $6 \mathrm{~km}$ above the altitude of the instrument, namely, above $8877 \mathrm{~m}$ asml, the HAMSTRAD measurements seem reasonable at the uppermost retrieval level (namely, $10 \mathrm{~km}, 12877 \mathrm{~m}$ asml). In May, the wet periods are systematically showing a good agreement between sonde and HAMSTRAD IWV fields and $\mathrm{H}_{2} \mathrm{O}$ below $6777 \mathrm{~m}$ asml but a dry bias of IASI by more than $4-\mathrm{kg} \mathrm{m}^{-2}$ IWV, whereas outside of these periods, the three data sets behave consistently. Since the best results (mean, standard deviation, bias, and correlation) are obtained when the HAMSTRAD radiometer operates in the very dry conditions of February, namely, in dryness conditions comparable to Dome $C$ summertime values, we are very confident in the optimal use of the instrument when deployed in Antarctica.
\end{abstract}

P. Ricaud and S. Derrien are with the Laboratoire d'Aérologie, Centre National de la Recherche Scientifique UMR 5560, Université de Toulouse, 31400 Toulouse, France.

B. Gabard is with the Office National d'Etudes et de Recherches Aérospatiales, 31400 Toulouse, France.

J.-L. Attié is with the Laboratoire d'Aérologie, Centre National de la Recherche Scientifique UMR, Université de Toulouse, 31400 Toulouse, France, and also with CNRM/CARMA, Météo-France, Toulouse, France.

T. Rose and H. Czekala are with the Radiometer Physics GmbH, 53340 Meckenheim, Germany (e-mail: philippe.ricaud@aero.obs-mip.fr).
Index Terms-Atmospheric measurements, humidity measurements, microwave measurements, validation.

\section{INTRODUCTION}

W ATER vapor $\left(\mathrm{H}_{2} \mathrm{O}\right)$ plays a key role in the Earth climate system, since it is the main greenhouse gas emitting and absorbing in the infrared domain. Its variability in both the troposphere and the stratosphere is still an enigma or, at least, is still under discussion [1]. Indeed, neither the positive trend in methane (stratospheric source) nor the negative trend in the tropopause temperature (direct injection from the troposphere to the stratosphere) can explain the positive trend in stratospheric $\mathrm{H}_{2} \mathrm{O}$ measured up to 2000 and the negative trend since then.

The $\mathrm{H}_{2} \mathrm{O}$ Antarctica Microwave Stratospheric and Tropospheric Radiometers (HAMSTRAD) program aims at developing two ground-based microwave radiometers to sound tropospheric and stratospheric $\mathrm{H}_{2} \mathrm{O}$ above Dome $\mathrm{C}$ (Concordia station), Antarctica $\left(75^{\circ} 06^{\prime} \mathrm{S}, 123^{\circ} 21^{\prime} \mathrm{E}, 3233 \mathrm{~m}\right.$ asml) over a long time period. HAMSTRAD-Tropo is a $183-\mathrm{GHz}$ radiometer for measuring tropospheric $\mathrm{H}_{2} \mathrm{O}$, which is the subject of this paper. HAMSTRAD-Strato is a microwave radiometer for measuring stratospheric $\mathrm{H}_{2} \mathrm{O}$ that is still under study based on the heritage of the microwave instruments developed at $22 \mathrm{GHz}[2]$.

This paper focuses on the validation of the first measurements of HAMSTRAD-Tropo (hereafter named HAMSTRAD) when the instrument was installed at the Pic du Midi (PdM) station $\left(42^{\circ} 56^{\prime} \mathrm{N}, 0^{\circ} 08^{\prime} \mathrm{E}, 2877 \mathrm{~m}\right.$ asml), France, in February-June 2008 prior to its deployment at Dome C in January 2009. Vertical profiles of absolute humidity and integrated water vapor (IWV) as measured by HAMSTRAD will be compared with measurements from radiosondes launched in three different sites: at the Lannemezan (LAN) station $\left(43^{\circ} 07^{\prime} \mathrm{N}, 0^{\circ} 23^{\prime} \mathrm{E}\right.$, $610 \mathrm{~m}$ asml), France $(\sim 30 \mathrm{~km}$ northeast from PdM), the Bordeaux-Mérignac Airport (BOR) station $\left(44^{\circ} 49^{\prime} \mathrm{N}, 0^{\circ} 42^{\prime} \mathrm{W}\right.$, $50 \mathrm{~m}$ asml), France ( $220 \mathrm{~km}$ northwest from PdM), and the Zaragoza (ZAR) station $\left(41^{\circ} 39^{\prime} \mathrm{N}, 0^{\circ} 53^{\prime} \mathrm{W}, 263 \mathrm{~m}\right.$ asml), Spain $(\sim 170 \mathrm{~km}$ southwest from PdM). The validation process also used the vertical profiles of tropospheric $\mathrm{H}_{2} \mathrm{O}$ as measured by the nadir-viewing infrared atmospheric sounding interferometer (IASI) instrument aboard the MetOp-A space platform. 
Section II will present the different data sets. The temporal evolution of the vertical profiles of $\mathrm{H}_{2} \mathrm{O}$ and IWV as measured by HAMSTRAD, IASI, and the sondes will be investigated in Section III. A statistical approach combining the monthly mean profiles, standard deviations, biases, and correlations against HAMSTRAD will also be discussed in Section III. Conclusions and perspectives will finalize this paper in Section IV.

\section{Measured Data Sets}

\section{A. HAMSTRAD}

The HAMSTRAD radiometer is presented in [3]. To synthesize, it uses spectral information in the domains $51-59 \mathrm{GHz}$ (oxygen line) and 169-197 GHz (water vapor line) to derive accurate tropospheric profiles of temperature (with accuracy ranging from 0.25 to $1.0 \mathrm{~K}$ ) and low absolute humidity (with accuracy ranging from 0.01 to $0.03 \mathrm{~g} \cdot \mathrm{m}^{-3}$ ), respectively, together with the IWV and the liquid water path.

Prior to its installation at Dome C in January 2009 [4], the fully automated radiometer has been deployed at the PdM station $\left(42^{\circ} 56^{\prime} \mathrm{N}, 0^{\circ} 08^{\prime} \mathrm{E}, 2877 \mathrm{~m}\right.$ asml $)$ in the Pyrenees Mountains, France, in February 2008 and was operational until June 2008. As presented in [3], preliminary comparisons with radio soundings particularly launched in the vicinity of PdM and the outputs from the mesoscale MESO-NH model [5] showed great consistency to within $0.2-0.3 \mathrm{~g} \cdot \mathrm{m}^{-3}$ between all absolute humidity data sets whatever the atmosphere considered (extremely dry or wet). The instrument also contains meteorological sensors to get the surface pressure, the temperature, and the relative humidity.

A statistical approach is used to calculate the profiles from the brightness temperatures (TBs) measured by the radiometer. The retrieval algorithms are based on a few thousands of radio soundings from Bordeaux-Mérignac, France, to build a statistically relevant database for the PdM station. From radiative transfer calculations using theoretical spectral models like [6] or [7], a corresponding set of TBs measured on the surface of the PdM station and at the radiometer frequencies is derived. Note that, although the stratospheric contribution might be non-negligible when the IWV is less than $1 \mathrm{~kg} \cdot \mathrm{m}^{-2}$ [8], the radiative transfer module does not contain information of stratospheric $\mathrm{H}_{2} \mathrm{O}$. Then, statistical fit algorithms are applied using linear regression to solve the inverse problem, namely, to estimate the humidity profiles from the TB sets. During radiometer operation, the statistical fit coefficients provide an online determination of the tropospheric profiles from the measured TBs. Consequently, the a priori information from the radio soundings is introduced into the retrievals. Nevertheless, the actual radiosonde profiles used in the intercomparison exercise are not entering the retrievals as a priori information.

The HAMSTRAD measurements almost continuously cover the period from February 8 to June 19, 2008 with a temporal resolution of $\sim 7 \mathrm{~min}$, while some power failures at the PdM station produced some gaps in the HAMSTRAD data set: February 18-20, May 5-6, and June 1-3, 11-13, and $15-16$. When statistically comparing with coincident IASI measurements, the HAMSTRAD profiles were selected within a 20-min window centered at the time of the IASI overpass within a $2^{\circ} \times 2^{\circ}$ latitude-longitude bin centered at the PdM location. When statistically comparing with coincident sonde measurements, the HAMSTRAD profiles were selected within a 20-min window starting at the time of the sounding launch. This typically corresponds to two to four HAMSTRAD $\mathrm{H}_{2} \mathrm{O}$ profiles contained in a 20-min window for both IASI and the sondes. Furthermore, we are making use of the meteorological parameters (hereafter named as in situ) provided by the HAMSTRAD external sensors (surface relative humidity transferred into absolute humidity) when comparing HAMSTRAD, IASI, and sonde measurements at the altitude of the PdM station, namely, $2877 \mathrm{~m}$ asml.

\section{B. Sondes}

The modem M2K2 and M2K2DC radiosondes were launched at $\mathrm{LAN}\left(43^{\circ} 07^{\prime} \mathrm{N}, 0^{\circ} 23^{\prime} \mathrm{E}, 610 \mathrm{~m}\right.$ asml), which is $\sim 30 \mathrm{~km}$ northeast from PdM, in February-March 2008 around 12:00 coordinated universal time (UTC) (see [3, Table III]) to validate HAMSTRAD. They were configured for temperature and humidity measurements. The reader should refer to [3] for a complete description of the sondes.

This dedicated program was in complement to the meteorological soundings routinely performed at 00:00 and 12:00 UTC (and, sometimes, at 06:00 and 18:00 UTC) in BOR $\left(44^{\circ} 49^{\prime} \mathrm{N}, 0^{\circ} 42^{\prime} \mathrm{W}, 50 \mathrm{~m}\right.$ asml), which is $\sim 220 \mathrm{~km}$ northwest from PdM, and in ZAR $\left(41^{\circ} 39^{\prime} \mathrm{N}, 0^{\circ} 53^{\prime} \mathrm{W}, 263 \mathrm{~m}\right.$ asml $)$, which is $\sim 170 \mathrm{~km}$ southwest from PdM. The reader should refer to http://weather.uwyo.edu/upperair/sounding.html to get dedicated information relative to the meteorological soundings.

\section{IASI}

The MetOp-A platform has been launched on October 19, 2006. It carries a set of eight instruments, including IASI, that potentially offer improved remote sensing capabilities for both meteorology and climatology. MetOp-A flies in a sunsynchronous polar orbit at a mean altitude of $\sim 815 \mathrm{~km}$. The orbit is inclined $98.7^{\circ}$ to the equator and crosses the equator (descending node) at 09:30 local solar time. The time for one orbit is 101 min with a repeat cycle of 29 days. The expected lifetime is five years.

The IASI instrument (see, e.g., http://smsc.cnes.fr/IASI) is a high-resolution infrared sounder that has been designed for the measurement of temperature and humidity profiles with accuracy better than $1 \mathrm{~K}$ and $10 \%$, respectively, for numerical weather prediction and climate models. IASI is an accurately calibrated Fourier transform spectrometer whose design is based on a classical Michelson interferometer. It covers the spectral range from $3.6 \mu \mathrm{m}\left(2760 \mathrm{~cm}^{-1}\right)$ to $15.5 \mu \mathrm{m}\left(645 \mathrm{~cm}^{-1}\right)$ with a spectral resolution between 0.35 and $0.5 \mathrm{~cm}^{-1}$. To achieve global coverage, the IASI instrument observes the Earth with a cross-track swath angle of $\pm 48.3^{\circ}$. The instrument field of view consists of four circular pixels of $0.8^{\circ}$ angular diameter, which corresponds to $12 \mathrm{~km}$ on the Earth at nadir. Within the spectral domain covered by IASI, a number of atmospheric constituents can also be measured: $\mathrm{O}_{3}, \mathrm{CO}_{2}, \mathrm{CH}_{4}, \mathrm{CO}$, and $\mathrm{N}_{2} \mathrm{O}$ (see [9] for this latter species). 


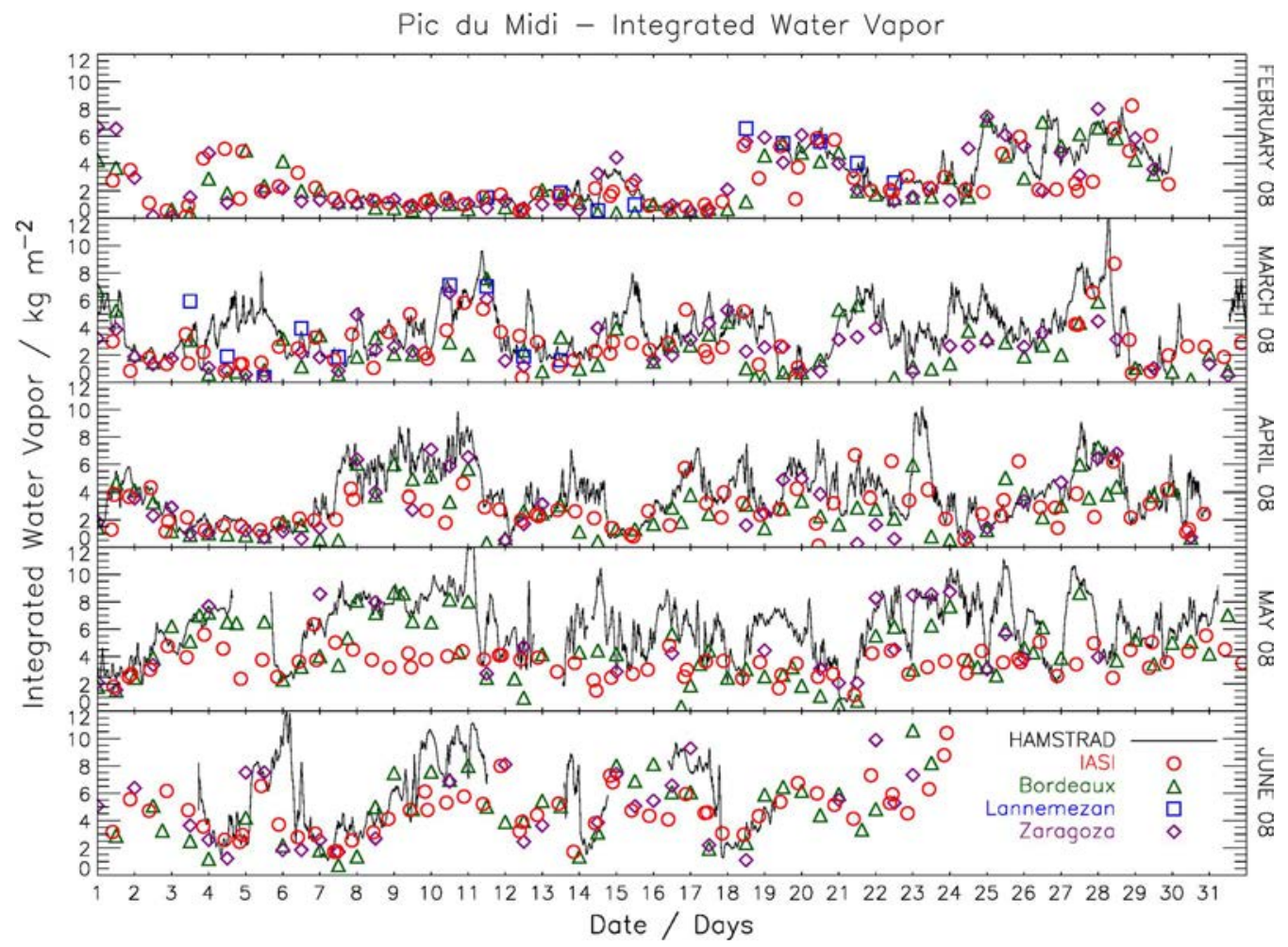

Fig. 1. IWV (in kilograms per square meter) inferred from the vertical profiles of absolute humidity above 2877-m altitude as measured by HAMSTRAD (black line), IASI (red circle), and the radiosondes from BOR (green triangle), LAN (blue square) and ZAR (purple diamond) from February to June 2008.

We are using the preoperational level-2 data (geophysical data) provided by EUMETSAT that produce near-real-time vertical profiles of $\mathrm{H}_{2} \mathrm{O}$ onto a fixed vertical pressure grid from 1000 to $0.1 \mathrm{hPa}$ with an accuracy of $10 \%$ [10]. For the methods used to retrieve the vertical profiles of $\mathrm{H}_{2} \mathrm{O}$, the reader should refer to [10] and [11]. The $\mathrm{H}_{2} \mathrm{O}$ vertical profiles provided by EUMETSAT for the period covering February-June 2008 have been selected within a $2^{\circ} \times 2^{\circ}$ bin (165 km along the longitude and $225 \mathrm{~km}$ along the latitude) centered at the location of the PdM station. Because the IASI instrument provides soundings from a cross-track scan with a 2200-km-wide swath, the actual number of IASI profiles selected in the $2^{\circ} \times 2^{\circ}$ bin is varying from 10 to 30 twice per day, around 09:00-10:00 and 21:00-22:00 UTC. The IASI $\mathrm{H}_{2} \mathrm{O}$ mass mixing ratio (in kilograms per kilograms) provided by EUMETSAT has been converted into absolute humidity (in grams per cubic meter), and the vertical scale has been transferred from the original pressure grid into an altitude grid by considering the geostrophic equilibrium equation and the surface pressure and temperature regularly measured at PdM by the HAMSTRAD in situ meteorological sensors. Note that all the IASI measurements were considered, irrespective of the presence of cloud in the line of sight.

\section{RESUlTS AND DISCUSSION}

\section{A. Temporal Evolution}

In this section, the temporal variations of absolute humidity as measured by the different instruments are consistently presented from February to June 2008 at selected altitudes (2877, 4877, 6777, 8477, 10877, and $12877 \mathrm{~m}$ asml) with the retrieval grid of the HAMSTRAD measurements. Sonde and IASI $\mathrm{H}_{2} \mathrm{O}$ profiles have been linearly interpolated onto the HAMSTRAD retrieval grid. For the profiles obtained above the altitude of the PdM $(2877 \mathrm{~m})$, the IWV has also been estimated for each data set. A complete statistical analysis will be presented in the next section discussing the mean values, standard deviations, biases, and correlations with respect to the HAMSTRAD measurements.

1) IWV: Fig. 1 shows the temporal evolutions of the IWV as deduced from HAMSTRAD, IASI, and the sondes launched in BOR, LAN, and ZAR. We can note the extreme variability of the atmosphere above PdM from extremely dry conditions encountered in February (IWV $<1 \mathrm{~kg} \cdot \mathrm{m}^{-2}$ ) to extremely wet conditions in June (IWV $>10 \mathrm{~kg} \cdot \mathrm{m}^{-2}$ ). The five data sets indeed track the same atmosphere with some agreements and differences that are worth mentioning.

From HAMSTRAD measurements, extremely dry conditions (IWV $\sim 1-2 \mathrm{~kg} \cdot \mathrm{m}^{-2}$ ) are encountered on February 7-17 and April 3-7. IASI and the sondes compare well with HAMSTRAD to within $0.2 \mathrm{~kg} \cdot \mathrm{m}^{-2}$. As already presented in [3], the period covering February 7-18 corresponds to a blocking anticyclone centered in Europe producing very cold and dry conditions above PdM. This is particularly encouraging for the installation of the HAMSTRAD instrument at Dome $\mathrm{C}$, where the IWV values are well below $1 \mathrm{~kg} \cdot \mathrm{m}^{-2}$ (see, e.g., [12]).

Extremely wet conditions (IWV $>6 \mathrm{~kg} \cdot \mathrm{m}^{-2}$ ) are encountered by HAMSTRAD at different occasions: February 18-20, 25, and 28; March 4-5, 10-11, and 27-28; April 8-11, 23, 


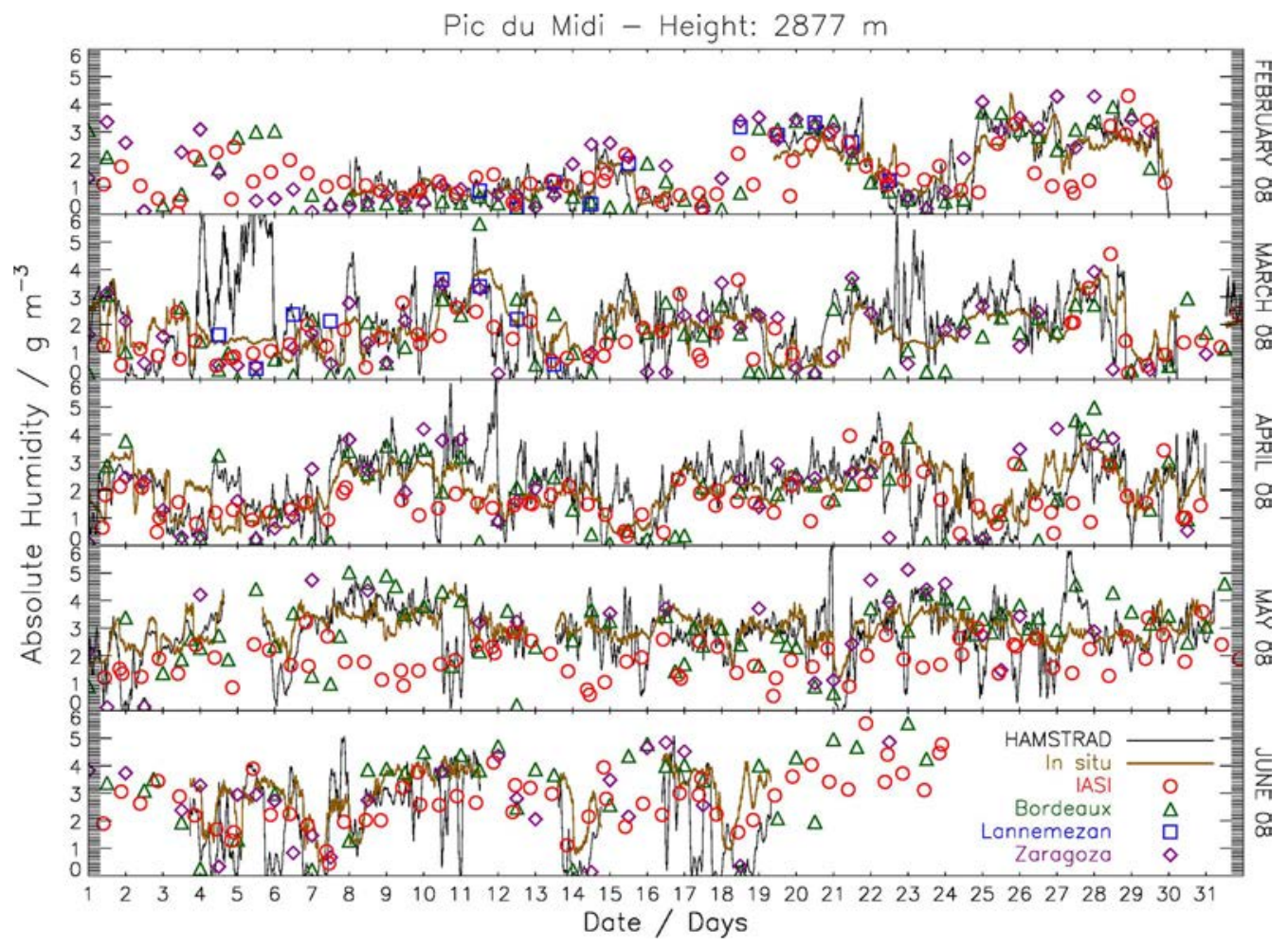

Fig. 2. Absolute humidity (in grams per cubic meter) at 2877-m altitude as measured by HAMSTRAD (black line), in situ sensors (brown line), IASI (red circle), and the radiosondes from BOR (green triangle), LAN (blue square), and ZAR (purple diamond) from February to June 2008.

and 27-28; May 7-11, 13-19, 22-25, and 27; and June 5-6, $9-12$, and $16-17$. On the average, the wet episodes are well reproduced by both the sondes and IASI with some marked exceptions. The period covering March 4-5, 2008 corresponds to a snow tempest over the Pyrenees Mountains. IASI and the sondes measured dry conditions (IWV $<2 \mathrm{~kg} \cdot \mathrm{m}^{-2}$ ), while the HAMSTRAD IWV was close to $6 \mathrm{~kg} \cdot \mathrm{m}^{-2}$. The HAMSTRAD measurements may well have been affected by the deposition of snow on the dielectric sheet enabling the atmospheric observations, and the automatic blower has certainly not been powerful enough to sweep the accumulated snow away. In May, the wet periods are systematically showing a good agreement between the sonde and HAMSTRAD IWV values but a dry bias of IASI by more than $4 \mathrm{~kg} \cdot \mathrm{m}^{-2}$, while outside of these periods, the three data sets behave consistently. At the present stage of our analysis, it is beyond the scope of this paper to explain why IASI showed such a dry bias, although we suspect that the presence of thick clouds during the wet periods may have considerably altered the IASI $\mathrm{H}_{2} \mathrm{O}$ retrievals.

2) $\mathrm{H}_{2} \mathrm{O}$ at $2877 \mathrm{~m}$ : The temporal evolution of the absolute humidity at the altitude of the HAMSTRAD radiometer $(2877 \mathrm{~m})$ as measured by HAMSTRAD, IASI, the sondes, and the in situ sensors is displayed in Fig. 2. Note that the HAMSTRAD retrievals at $2877 \mathrm{~m}$ (lowermost retrieval layer) are not constrained by the meteorological sensor measurements; consequently, the in situ and HAMSTRAD data sets can be considered as independent.

The HAMSTRAD $\mathrm{H}_{2} \mathrm{O}$ evolution at $2877 \mathrm{~m}$ is indeed very consistent with the HAMSTRAD IWV because of the strong weight of the lowermost levels when calculating the IWV from a vertical profile. The HAMSTRAD $\mathrm{H}_{2} \mathrm{O}$ shows the same extremely dry $\left(<1 \mathrm{~g} \cdot \mathrm{m}^{-3}\right)$ and wet $\left(>3 \mathrm{~g} \cdot \mathrm{m}^{-3}\right)$ periods. On the average, in situ, IASI, HAMSTRAD, and the sondes again track the same atmosphere. The agreement with in situ measurements is indeed extremely good, except for the alreadymentioned period covering March 4-5 when HAMSTRAD measurements were affected by a snow tempest. The same disagreement happened on March 22-23, during which a snow event and an extremely intense rain event occurred that certainly perturbed the HAMSTRAD measurements. On these two events, IASI and the sondes are very consistent with the in situ measurements. There are also very few events when the HAMSTRAD absolute humidity is much less by $\sim 2 \mathrm{~g} \cdot \mathrm{m}^{-3}$ than the in situ $\mathrm{H}_{2} \mathrm{O}$ (May 10 and June 6 and 18-19), but the other data sets (sondes and IASI) are lying between the two. Thus, no definitive conclusions can be drawn regarding these particular events since they are not associated to any unusual meteorological situations. Note the systematic low $\mathrm{H}_{2} \mathrm{O}$ IASI amounts in May that we already noticed when considering the IWV data sets.

3) $\mathrm{H}_{2} \mathrm{O}$ at $4877 \mathrm{~m}$ : The absolute humidity measured $2 \mathrm{~km}$ above the PdM site $(4877 \mathrm{~m}$ ) by HAMSTRAD, IASI, and the sondes can be seen in Fig. 3. We can draw the same conclusions as those at $2877 \mathrm{~m}$ with an overall good agreement within all the data sets, particularly in February-April, with dry $\left(<0.5 \mathrm{~g} \cdot \mathrm{m}^{-3}\right)$ and wet $\left(>1.5 \mathrm{~g} \cdot \mathrm{m}^{-3}\right)$ periods. In May and June, there is a much greater variability within the data sets. HAMSTRAD systematically measures a wet atmosphere, while IASI detects a systematically dry atmosphere, with the sondes oscillating between the two data sets.

4) $\mathrm{H}_{2} \mathrm{O}$ at $6777 \mathrm{~m}$ : At the altitude of $6777 \mathrm{~m}(3900 \mathrm{~m}$ above the PdM station), the temporal evolution of the measured 


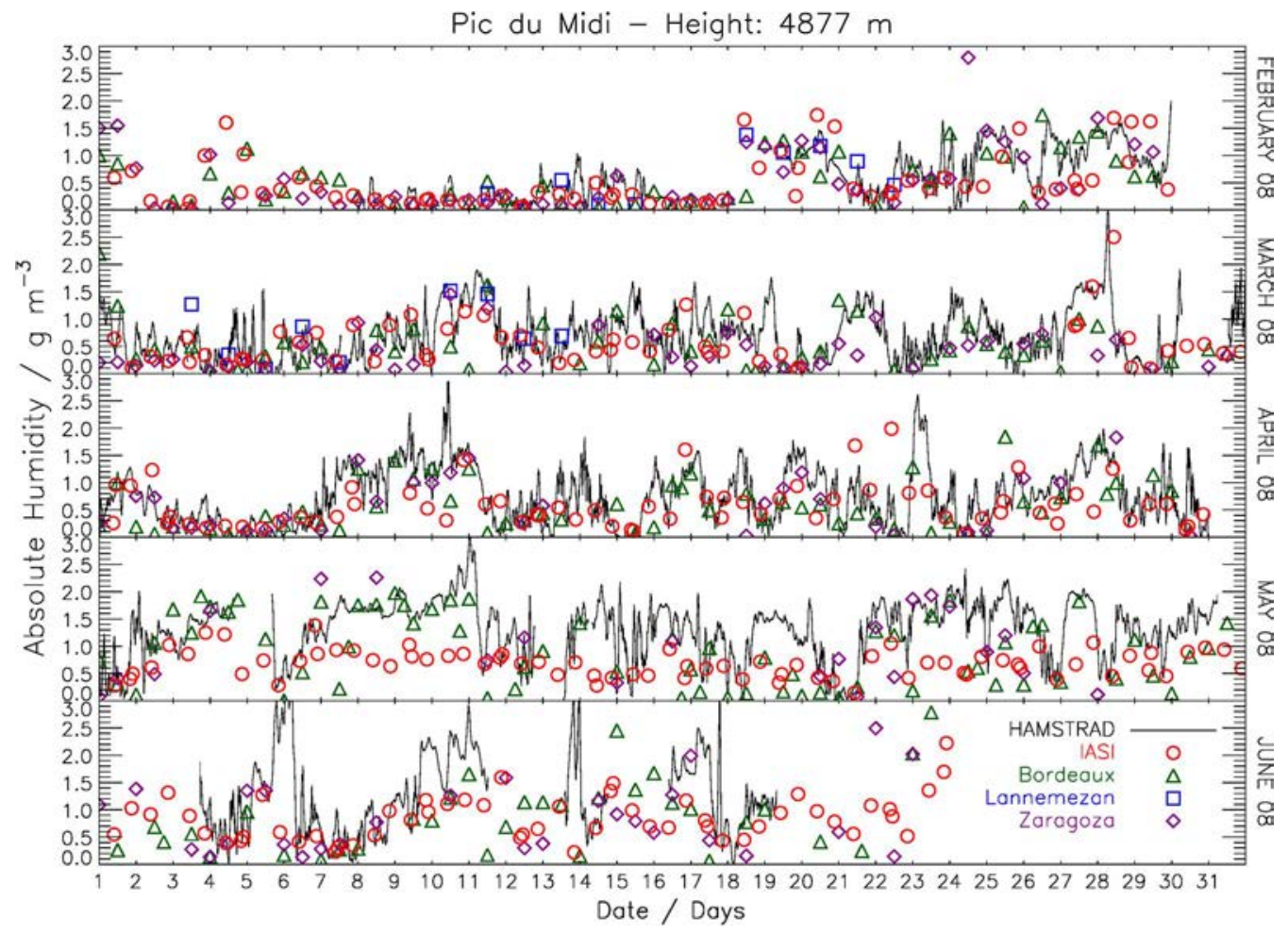

Fig. 3. Same as Fig. 2 but for 4877-m altitude.

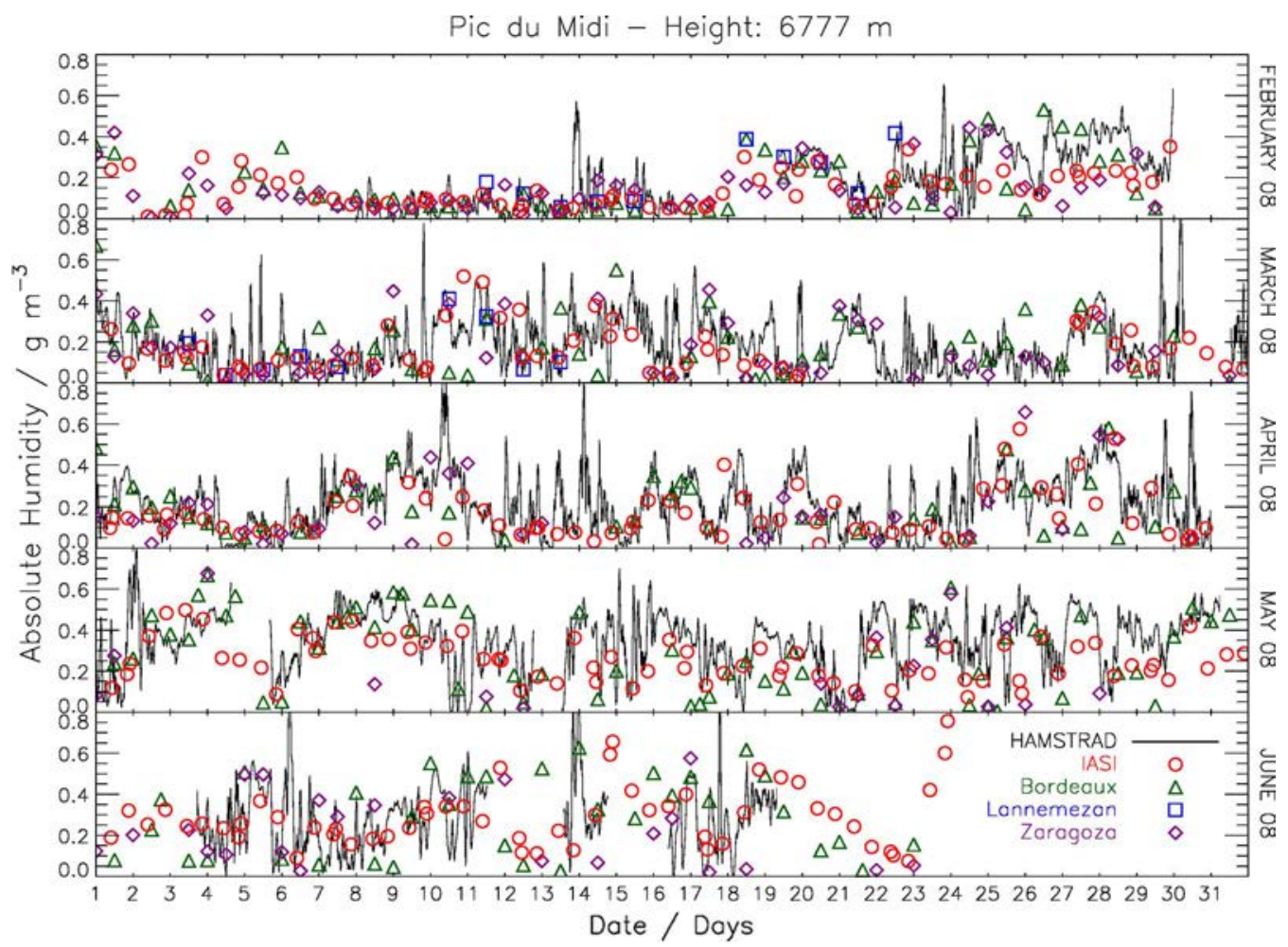

Fig. 4. Same as Fig. 2 but for $6777-m$ altitude.

absolute humidity (Fig. 4) is again very consistent within the four data sets. Dry $\left(<0.1 \mathrm{~g} \cdot \mathrm{m}^{-3}\right)$ and wet $\left(>0.4 \mathrm{~g} \cdot \mathrm{m}^{-3}\right)$ periods are clearly detected along the five-month period with no obvious systematic bias between HAMSTRAD and IASI in May and June, contrary to what we already mentioned for altitudes below $6777 \mathrm{~m}$.
5) $\mathrm{H}_{2} \mathrm{O}$ at $8477 \mathrm{~m}$ : At the altitude of $8477 \mathrm{~m}(5600 \mathrm{~m}$ above the PdM station), there are very few soundings available from the BOR station. The temporal evolution of absolute humidity from the four data sets is shown in Fig. 5. The HAMSTRAD $\mathrm{H}_{2} \mathrm{O}$ exhibits a February-June increase from $<0.02 \mathrm{~g} \cdot \mathrm{m}^{-3}$ to $>0.10 \mathrm{~g} \cdot \mathrm{m}^{-3}$ but has a weak monthly 


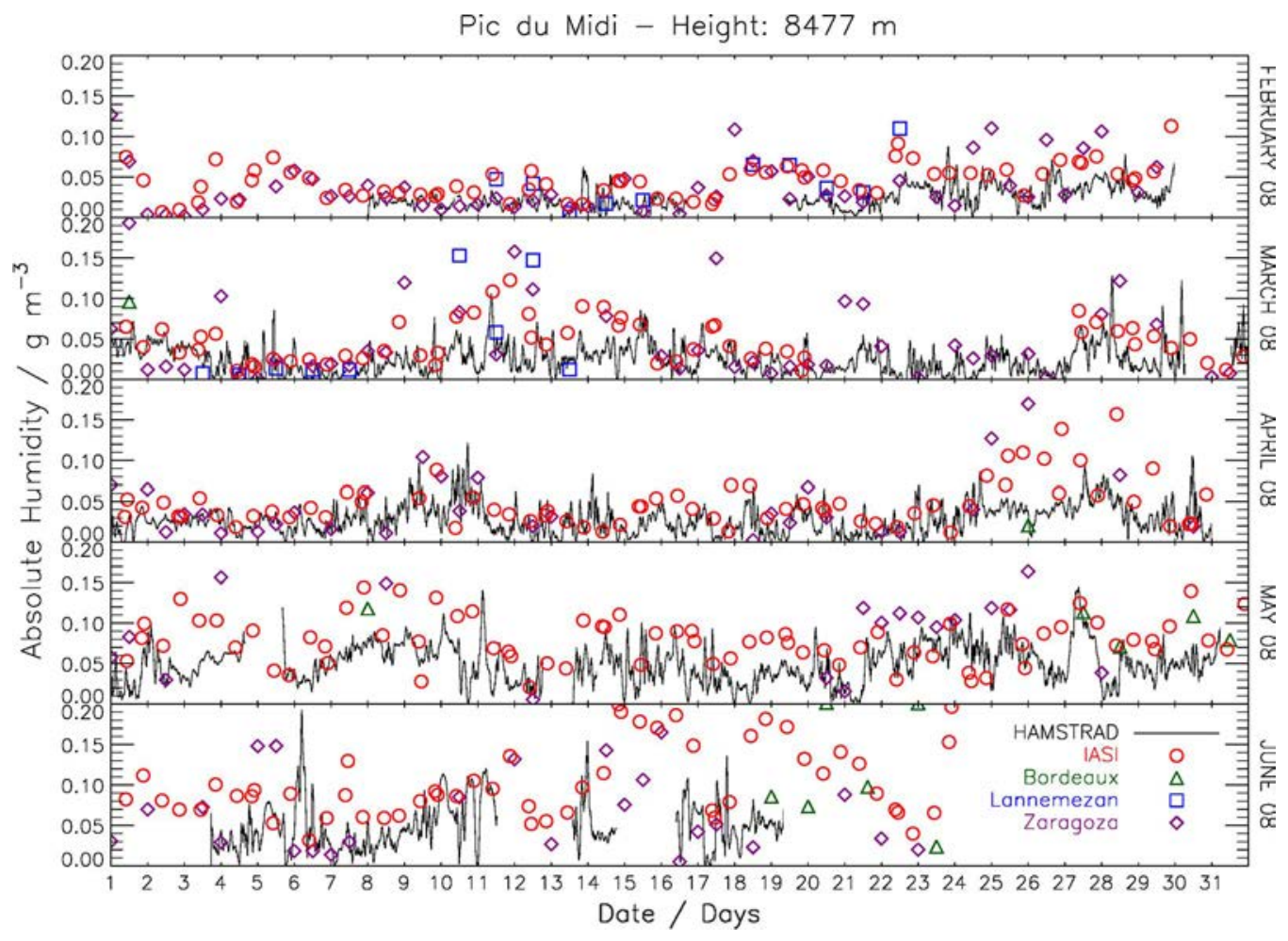

Fig. 5. Same as Fig. 2 but for $8477-\mathrm{m}$ altitude.

variability of about $0.02-0.03 \mathrm{~g} \cdot \mathrm{m}^{-3}$. IASI and the sondes also show a February-June $\mathrm{H}_{2} \mathrm{O}$ increase of the same amplitude but associated with a much greater monthly variability of about $0.03-0.05 \mathrm{~g} \cdot \mathrm{m}^{-3}$. In addition, for periods when the IASI and sonde $\mathrm{H}_{2} \mathrm{O}$ values are greater than or on the order of $0.10 \mathrm{~g} \cdot \mathrm{m}^{-3}$, the HAMSTRAD $\mathrm{H}_{2} \mathrm{O}$ is systematically lower $\left(0.03-0.05 \mathrm{~g} \cdot \mathrm{m}^{-3}\right)$.

6) $\mathrm{H}_{2} \mathrm{O}$ at $10877 \mathrm{~m}$ : At $10877 \mathrm{~m}(8 \mathrm{~km}$ above the $\mathrm{PdM}$ station), HAMSTRAD measurements $\left(<510^{-3} \mathrm{~g} \cdot \mathrm{m}^{-3}\right)$ are systematically much less than IASI and the LAN and ZAR sonde (BOR sondes do not reach this altitude) measurements (5-25 $\left.10^{-3} \mathrm{~g} \cdot \mathrm{m}^{-3}\right)$. Nevertheless, the February-June $\mathrm{H}_{2} \mathrm{O}$ increase is well depicted in all the data sets (Fig. 6).

7) $\mathrm{H}_{2} \mathrm{O}$ at $12877 \mathrm{~m}$ : At the uppermost HAMSTRAD retrieval layer $(12877 \mathrm{~m}$, thus being $10 \mathrm{~km}$ above the PdM station), the four data sets show similar amounts of absolute humidity, increasing from $\sim 10^{-3} \mathrm{~g} \cdot \mathrm{m}^{-3}$ in February to $\sim 210^{-3} \mathrm{~g} \cdot \mathrm{m}^{-3}$ in June (Fig. 7). The monthly variability is rather weak $\left(0.210^{-3} \mathrm{~g} \cdot \mathrm{m}^{-3}\right)$ in February for all the data sets but rather strong in May and June $\left(\sim 210^{-3} \mathrm{~g} \cdot \mathrm{m}^{-3}\right)$. The HAMSTRAD $\mathrm{H}_{2} \mathrm{O}$ has some non-negligible spikes during the period of the snow tempest (March 4-5), but others are not reproduced by neither IASI nor the sondes (May 10-11 and June 10-11 and 16-17). Interestingly, associated to the HAMSTRAD spikes on May 14 and 23-24 are two peaks in the IASI data on May 14 and 23, respectively. On the other hand, the $\mathrm{H}_{2} \mathrm{O}$ maxima $\left(2-410^{-3} \mathrm{~g} \cdot \mathrm{m}^{-3}\right)$ detected by IASI and the sondes on March 1-3, April 24-28, and May 1-5 were not measured by HAMSTRAD.

To conclude on the temporal evolution of the HAMSTRAD $\mathrm{H}_{2} \mathrm{O}$ measurements above the PdM station, by considering
IASI, sonde, and in situ measurements, we can state that all the data sets have tracked the same atmosphere from a dry period in February to a wet period in June. HAMSTRAD showed unrealistic values in periods of well-established snow tempest. The sensitivity of the HAMSTRAD measurements tends to be degraded $6 \mathrm{~km}$ above the altitude of the instrument (above $8877 \mathrm{~m}$ asml), while at the uppermost HAMSTRAD retrieval level $(10 \mathrm{~km}, 12877 \mathrm{~m}$ asml), the HAMSTRAD measurements seem reasonable.

\section{B. Statistical Analysis}

In this section, we perform a statistical analysis of all the absolute humidity fields measured by HAMSTRAD, sondes, IASI, and in situ sensors considering the means and standard deviations for each month during the period covering February-June 2008 and globally during the five-month period. Furthermore, we also calculate the biases and correlations of sonde, IASI, and in situ sensor measurements with respect to coincident HAMSTRAD measurements for each month during the period covering February-June 2008 and globally during the five-month period.

1) Mean Profile: From Fig. 8, in the dry conditions encountered in February, all the monthly averaged profiles, including in situ mean values at $2877 \mathrm{~m}$, are very consistent to within $0.1-0.2 \mathrm{~g} \cdot \mathrm{m}^{-3}$. In standard and wet conditions (March-June), HAMSTRAD measurements tend to show an atmosphere wetter by $0.1-0.3 \mathrm{~g} \cdot \mathrm{m}^{-3}$ than that of IASI and sonde measurements. There is a notable exception in May when IASI again tends to measure an atmosphere much drier (by $0.1-1.0 \mathrm{~g} \cdot \mathrm{m}^{-3}$ ) than that of HAMSTRAD and the sondes. 
Pic du Midi - Height: 10877 m

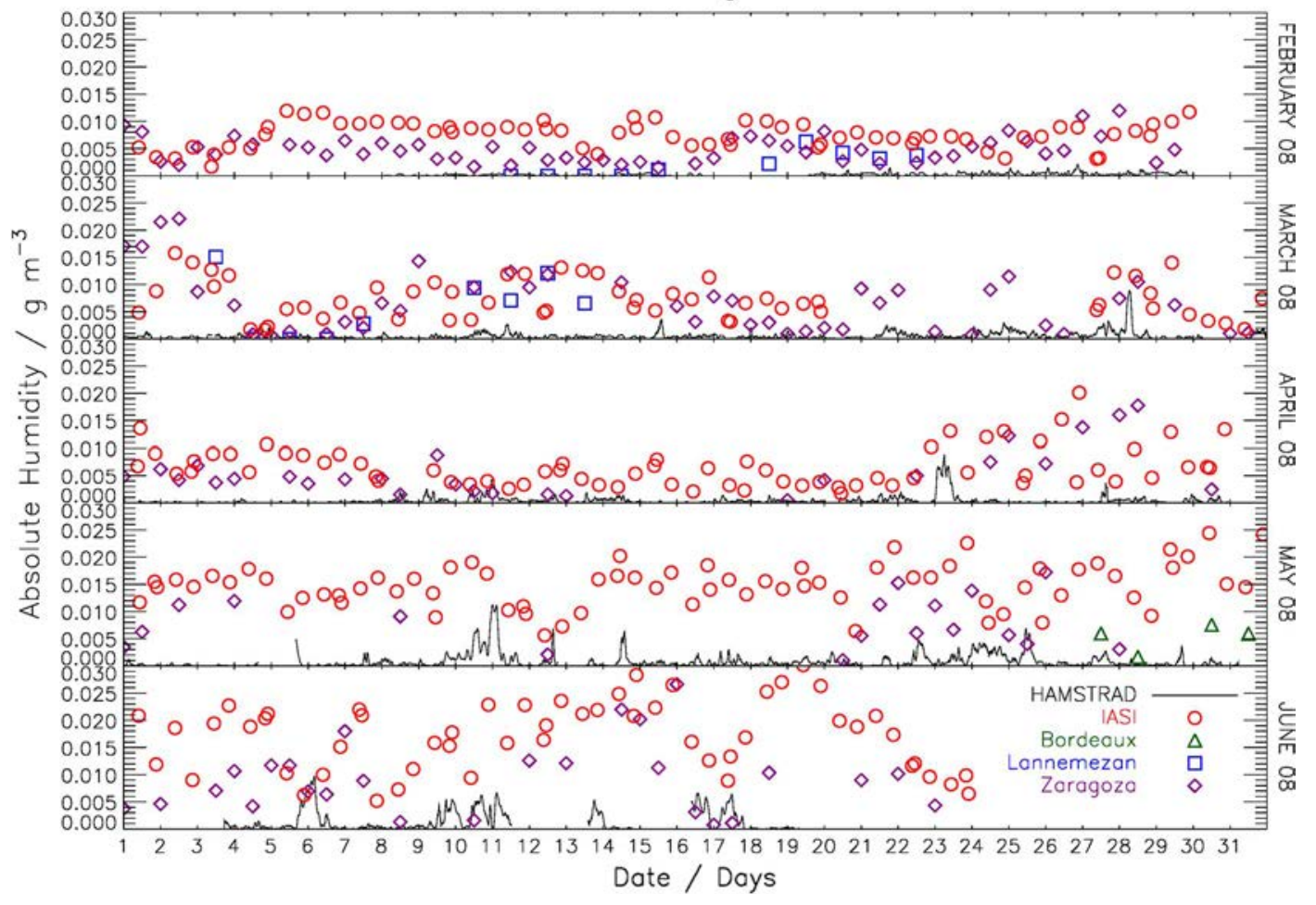

Fig. 6. Same as Fig. 2 but for $10877-\mathrm{m}$ altitude.

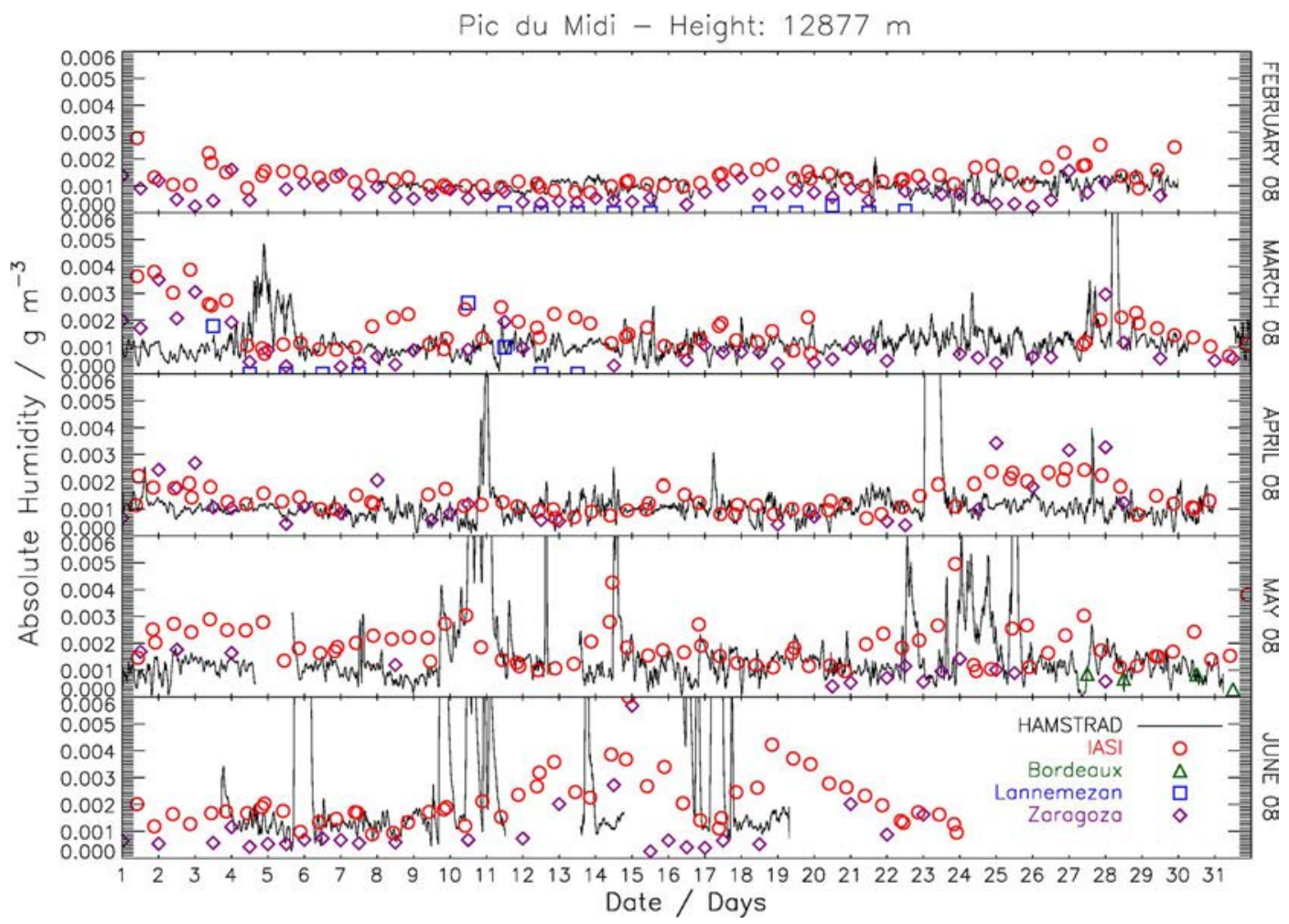

Fig. 7. Same as Fig. 2 but for $12877-\mathrm{m}$ altitude.

At $2877 \mathrm{~m}$, the in situ monthly averaged measurements are very consistent with HAMSTRAD and the sondes in April and May. In March, HAMSTRAD is greater by $0.2 \mathrm{~g} \cdot \mathrm{m}^{-3}$ than in situ (influence of the snow tempest episode on the monthly average). In June, HAMSTRAD is less by $\sim 1 \mathrm{~g} \cdot \mathrm{m}^{-3}$ than in situ for reasons that may be linked to the influence of a non-negligible number of rainy and heavy cloudy days on the average. Note that, for altitudes between 9 and $12 \mathrm{~km}$, 
Pic du Midi / Monthly-averaged Absolute Humidity
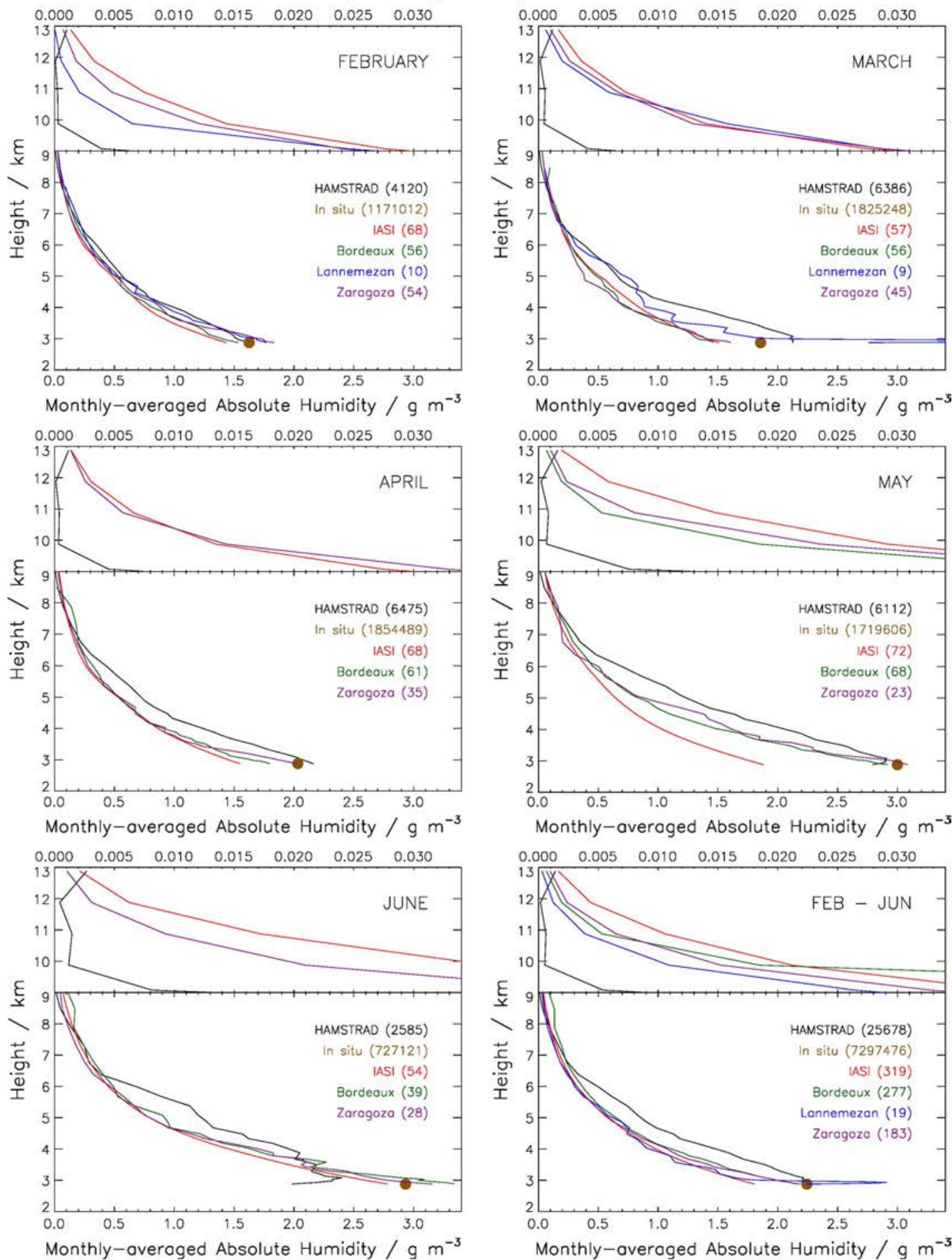

Fig. 8. Monthly and five-month averaged vertical profiles of absolute humidity as measured by HAMSTRAD (black line), in situ (filled brown circle), IASI (red line), and the radiosondes from BOR (green line), LAN (blue line), and ZAR (purple line) from February to June 2008. The number of profiles or points used in the monthly or five-month averaging is noted between brackets for each set of data. Also note that, to cope for the weak values of absolute humidity above $9 \mathrm{~km}$, the $x$-axis has a range of $0-3.5$ and $0-0.035 \mathrm{~g} \cdot \mathrm{m}^{-3}$ when the $y$-axis has a range of $0-9$ and $9-13 \mathrm{~km}$, respectively.

HAMSTRAD is systematically less than the other data sets by $0.005-0.015 \mathrm{~g} \cdot \mathrm{m}^{-3}$. This negative bias could be related to the following: 1) the modeling of the atmosphere (stratospheric contributions are not taken into account; radiosondes as a priori information are not available at the PdM station) and 2 ) the suboptimal use of the HAMSTRAD instrument (nominal in cold and dry environments; channels are selected for the Dome C station).

2) Standard Deviation: Whatever the period considered, the absolute standard deviation of the HAMSTRAD and the sonde measurements are very consistent to within $0.1 \mathrm{~g} \cdot \mathrm{m}^{-3}$ (Fig. 9). The IASI absolute standard deviation systematically appears 
Pic du Midi / Monthly-averaged Standard Deviation
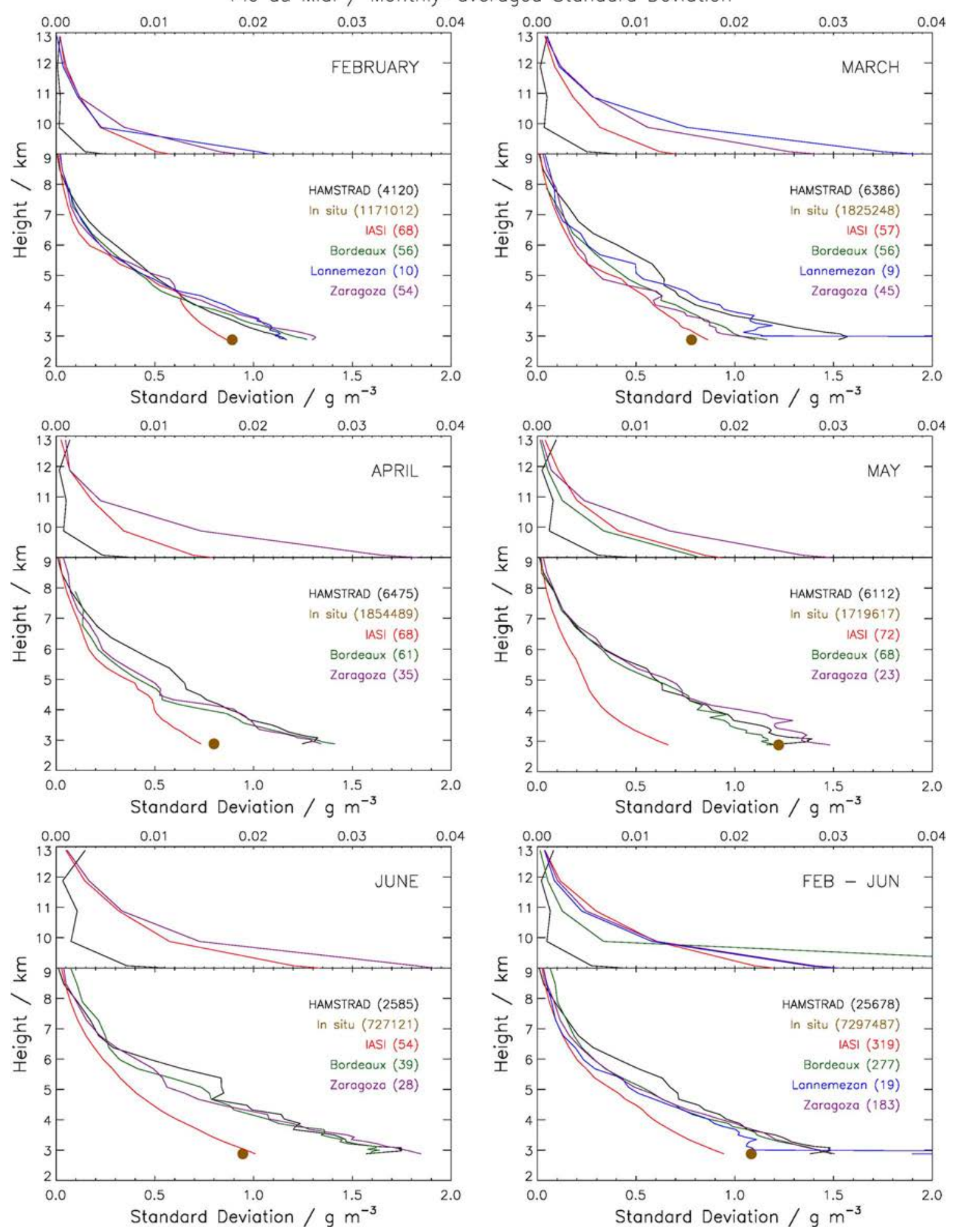

Fig. 9. Same as Fig. 8 but for the absolute standard deviation (in grams per cubic meter).

to be much lower by $0.2-0.8 \mathrm{~g} \cdot \mathrm{m}^{-3}$ than the HAMSTRAD and sonde absolute standard deviations, particularly during wet periods (May-June). Nevertheless, if we exclude the period of May, the absolute standard deviation of IASI at $2877 \mathrm{~m}$ is in very good agreement with the in situ measurements from February to June. Again, during the month of May, it appears that the IASI $\mathrm{H}_{2} \mathrm{O}$ measurements were seriously degraded above the PdM station.

It is very helpful to consider the standard deviations relative to the mean because of the great dynamical range in the $\mathrm{H}_{2} \mathrm{O}$ vertical profiles versus height (Fig. 10). Indeed, in dry conditions (February), all data sets show a relative standard deviation 
Pic du Midi / Monthly-averaged Standard Deviation
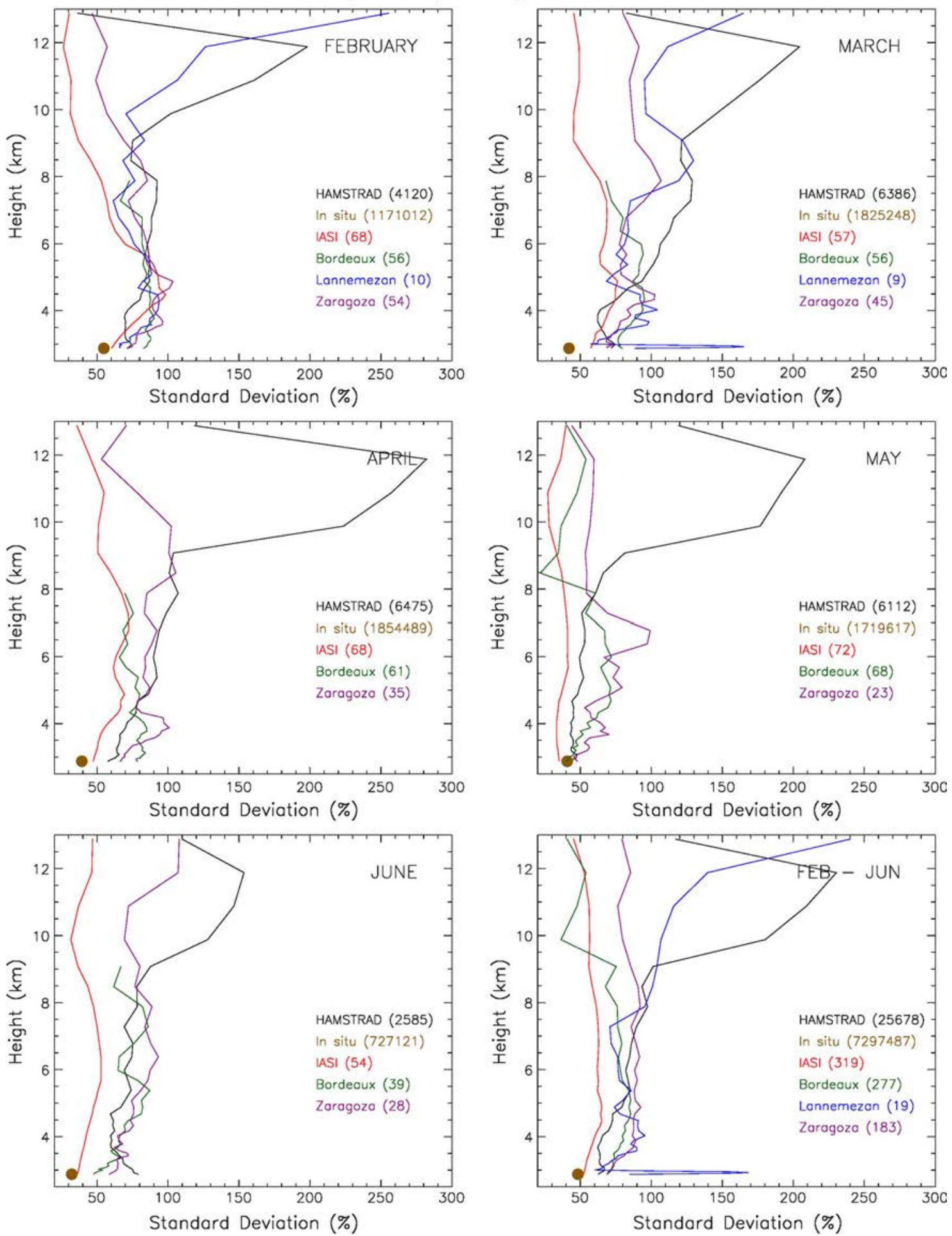

Fig. 10. Same as Fig. 9 but for the standard deviation relative to the mean (in percentage).

increasing from $50 \%$ to $80 \%$ at the PdM altitude to around 5-km altitude with an amplitude of $80 \%-100 \%$ and decreasing down to $50 \%-80 \%$ at $8 \mathrm{~km}$ altitude. Above $8-\mathrm{km}$ altitude, there is nonconsistency between all the data sets: some are decreasing with height (IASI and ZAR), while some are increasing with height (HAMSTRAD and BOR). During the other periods (standard and wet), there is a great consistency between the
HAMSTRAD and sonde relative standard deviations in April and June $(60 \%-80 \%)$, while in May, HAMSTRAD is much lower than the sonde measurements, and the converse is true in March. The IASI relative standard deviations are systematically lower $(30 \%-70 \%)$ than the other data sets.

3) Bias: When considering the bias of the different data sets (IASI and the sondes) against HAMSTRAD, we are 

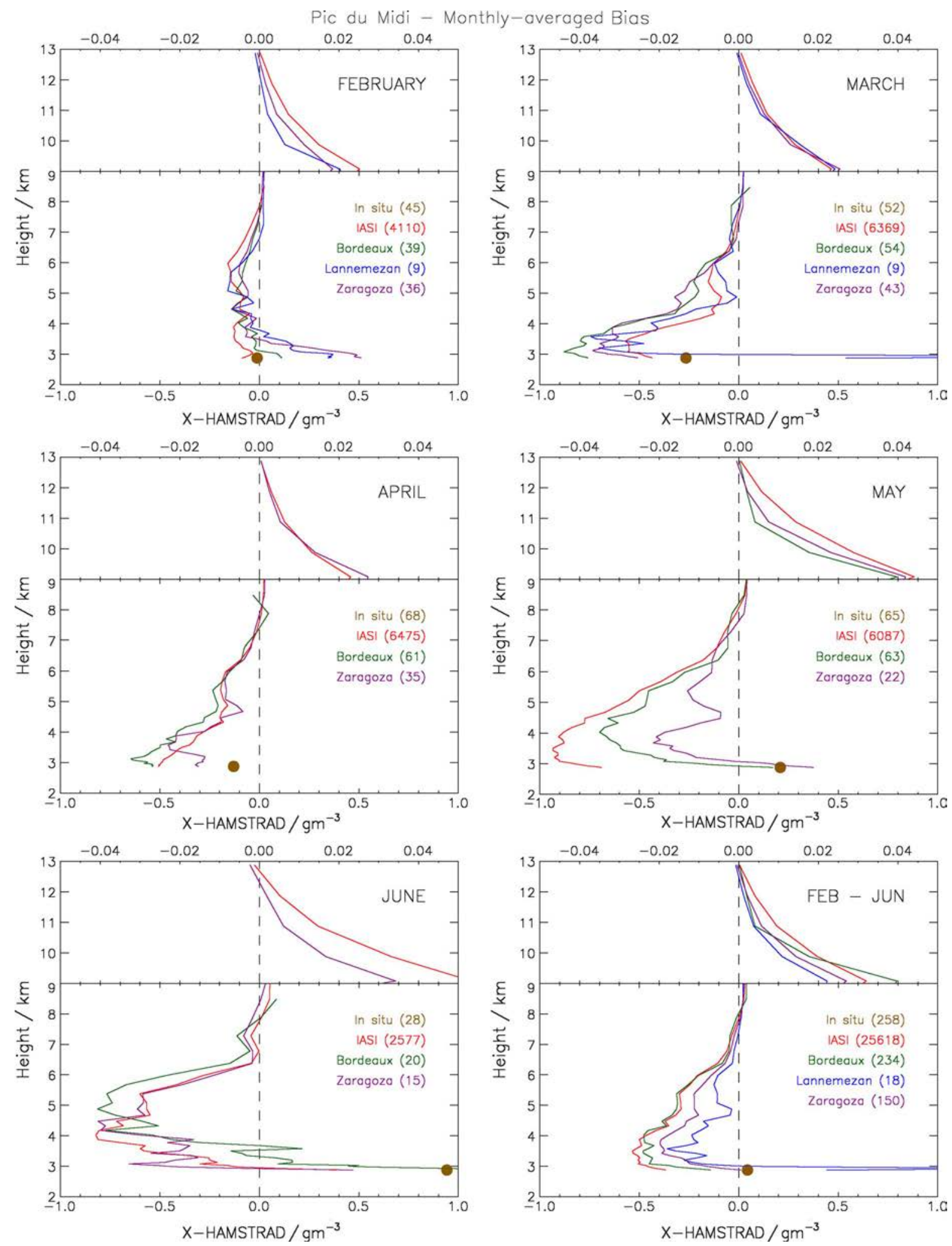

Fig. 11. Same as Fig. 8 but for the bias between all the data sets and HAMSTRAD (in grams per cubic meter).

essentially dealing with coincident measurements, as detailed in Section II, explaining why there are, on the average, fewer measurements taken into account. For instance, in February, even if 68 measurements of IASI can be selected in the vicinity of the PdM, only 45 IASI measurements are in coincidence with HAMSTRAD measurements. Despite the reduction in the number of measurements used in the analysis, some obvious conclusions can be drawn from Fig. 11. First, in very dry conditions (February), all the data sets are consistent to within $0.1-0.2 \mathrm{~g} \cdot \mathrm{m}^{-3}$, except in the very first $500 \mathrm{~m}$ above the station of the PdM, where the ZAR and BOR sondes tend to show a positive bias of $0.4-0.5 \mathrm{~g} \cdot \mathrm{m}^{-3}$. For the other periods (standard 
Pic du Midi - Absolute Humidity Bias
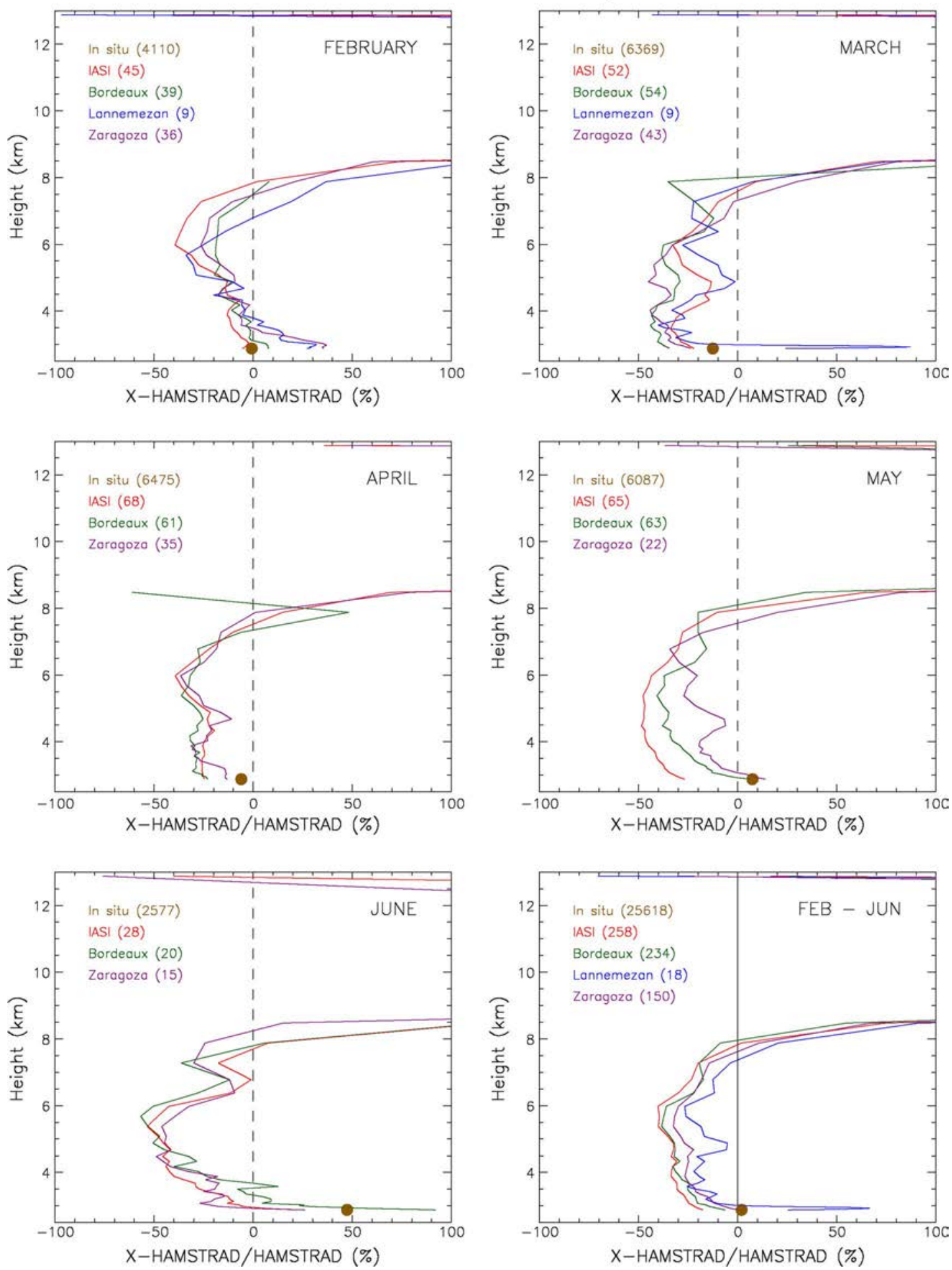

Fig. 12. Same as Fig. 11 but for the relative bias between all the data sets and HAMSTRAD (in percentage).

and wet periods from March to June), the bias is systematically negative up to about $-1 \mathrm{~g} \cdot \mathrm{m}^{-3}$ in May for IASI. Consequently, IASI tends to be in good agreement with the sondes to within $0.1 \mathrm{~g} \cdot \mathrm{m}^{-3}$, except in May, and HAMSTRAD measures a wetter atmosphere, except in February. Interestingly, at the PdM altitude, the absolute bias between in situ and HAMSTRAD measurements is negligible, while it is negative in March and April (from -0.1 to $-0.3 \mathrm{~g} \cdot \mathrm{m}^{-3}$ ) and positive in May and
June (from 0.2 to $1.0 \mathrm{~g} \cdot \mathrm{m}^{-3}$ ), being rather consistent with BOR sondes. Note that, in the upper troposphere (altitude above $9 \mathrm{~km}$ ), HAMSTRAD tends to measure an atmosphere much drier than that of the sondes and IASI by $0.02-$ $0.04 \mathrm{~g} \cdot \mathrm{m}^{-3}$.

The bias relative to the HAMSTRAD absolute humidity mean is again worth studying (Fig. 12). Indeed, whatever the period considered (dry/standard/wet), the bias between IASI 
Pic du Midi - Absolute Humidity Correlation
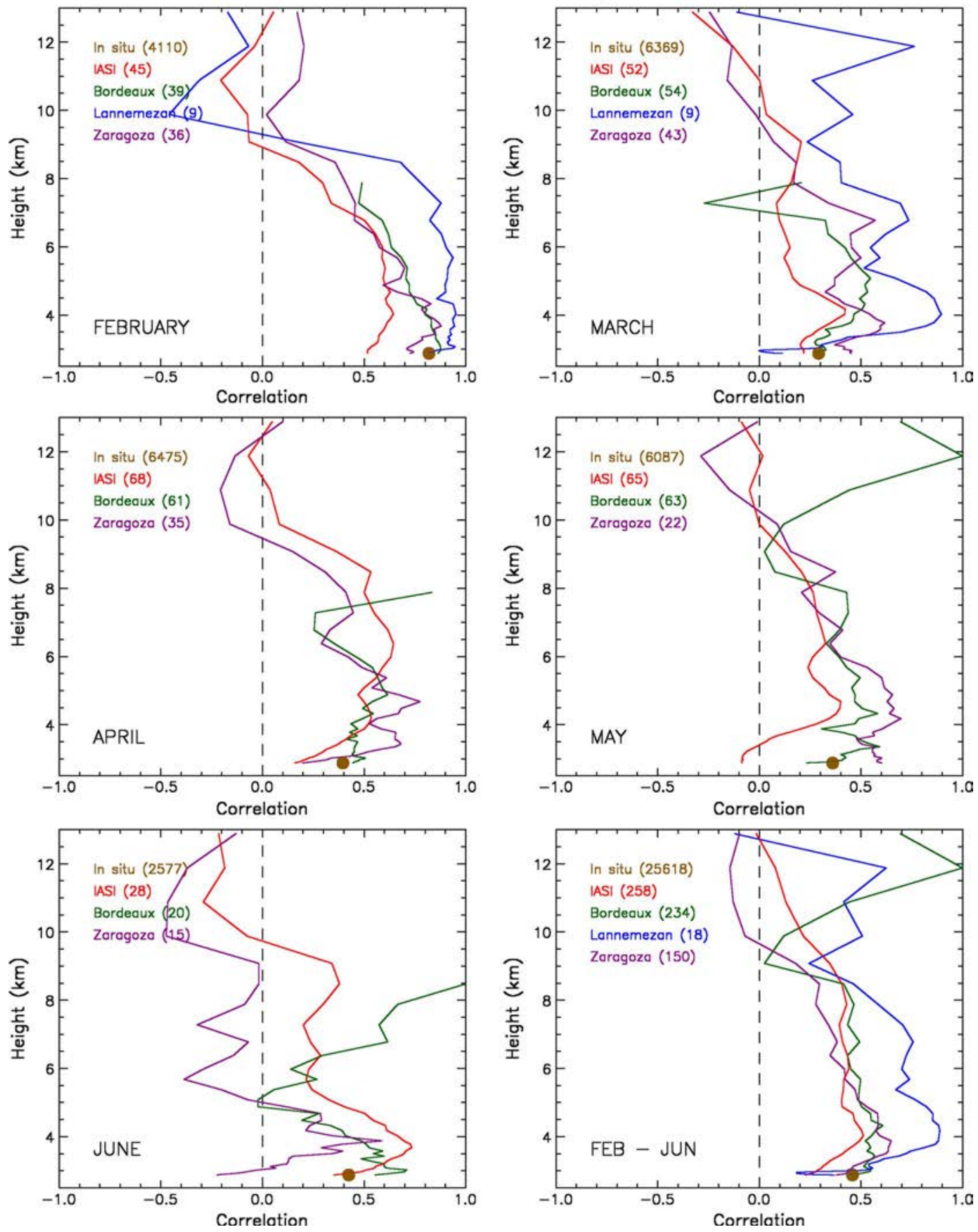

Fig. 13. Same as Fig. 8 but for the correlation between all the data sets and HAMSTRAD.

and the sondes relative to HAMSTRAD is comprised between $-50 \%$ and $+50 \%$ from the PdM altitude up to $\sim 8-\mathrm{km}$ altitude and strongly diverges above ( $\gg 50 \%)$. There are two obvious exceptions: 1) at the altitude of the PdM (namely, the first HAMSTRAD retrieval layer), where the relative bias with LAN in March and ZAR in June reaches 90\%, and 2) at $12877 \mathrm{~m}$ (namely, the last HAMSTRAD retrieval layer), where the relative bias with IASI and ZAR and LAN can converge to within the $[-50 \% ;+50 \%]$ range, thus probably indicating a net sensitivity of HAMSTRAD in the uppermost retrieval layer.

4) Correlation: Finally, the correlation rate between coincident measurements of IASI and the sonde relative to the measurements of HAMSTRAD are shown in Fig. 13. On the average, over the whole period, the correlation rate tends to decrease from the altitude of the PdM (0.5-0.6) to $12-\mathrm{km}$ height, underlining the loss in sensitivity of the HAMSTRAD instrument upon reaching the upper troposphere. Nevertheless, if we consider the different periods, we can notice that, in February (dry conditions), the correlation rate between the sondes and HAMSTRAD is very good, ranging $0.7-0.9$ in the first few kilometers above the PdM altitude, while the IASI-HAMSTRAD correlation rate is much less, reaching $0.5-0.6$. For the other periods (standard and wet from March to June), the correlation rate with HAMSTRAD is not that high 
(0.3-0.6), with some very low values for IASI in May within $1 \mathrm{~km}$ above the PdM altitude. At the PdM altitude, the correlation of HAMSTRAD versus in situ is again very good in February $(\sim 0.80)$ and tends to be worse in standard and dry conditions from March to June (0.30-0.45).

\section{CONCLUSION}

The HAMSTRAD 183-GHz radiometer has been particularly developed to measure vertical profiles of water vapor above the Dome C station in Antarctica. Prior to its installation in January 2009, it has been deployed at the PdM station in the Pyrenees Mountains over the period covering February-June 2008. To validate the tropospheric $\mathrm{H}_{2} \mathrm{O}$ measurements of HAMSTRAD, we have used IASI and radiosonde $\mathrm{H}_{2} \mathrm{O}$ vertical profiles in two different approaches. First, we have studied the temporal evolution of all the data sets over the five-month period. Second, we have statistically estimated the monthly averages, standard deviations, biases, and correlation rates of all the data sets relative to HAMSTRAD.

The temporal evolution of the HAMSTRAD $\mathrm{H}_{2} \mathrm{O}$ measurements above the PdM station is very consistent with IASI, sonde, and in situ measurements, tracking the same atmosphere from a dry period in February to a wet period in June. HAMSTRAD showed unrealistic values in periods of well-established snow tempest. While the sensitivity of the HAMSTRAD measurements tends to be degraded $6 \mathrm{~km}$ above the altitude of the instrument, namely, above $8877 \mathrm{~m}$ asml, the HAMSTRAD measurements seem reasonable at the uppermost retrieval level (namely, $10 \mathrm{~km}, 12877 \mathrm{~m}$ asml). In May, the wet periods are systematically showing a good agreement between sonde and HAMSTRAD IWV fields and $\mathrm{H}_{2} \mathrm{O}$ measurements below $6777 \mathrm{~m}$ asml but a dry bias of IASI by more than 4-kg m ${ }^{-2}$ IWV, while outside of these periods, the three data sets behave consistently.

In the dry conditions of February (optimal conditions for HAMSTRAD operation), the mean profiles of all the data sets are very consistent to within $0.1-0.2 \mathrm{~g} \cdot \mathrm{m}^{-3}$, with a weak bias $\left(0.1-0.2 \mathrm{~g} \cdot \mathrm{m}^{-3}\right)$ and a high correlation rate $(0.7-0.9)$ with HAMSTRAD measurements, while the standard deviation of IASI data is less than that of HAMSTRAD and the sondes by $0.3 \mathrm{~g} \cdot \mathrm{m}^{-3}$. From March to June (suboptimal conditions for HAMSTRAD operation), HAMSTRAD measurements tend to show an atmosphere wetter by $0.1-0.3 \mathrm{~g} \cdot \mathrm{m}^{-3}$ than that of IASI and sonde measurements, with a bias against HAMSTRAD that is systematically negative (up to about $-1 \mathrm{~g} \cdot \mathrm{m}^{-3}$ in May for IASI) and a weak correlation rate ranging from 0.3 to 0.6 . There is a notable exception in May when IASI again tends to measure an atmosphere much drier (by $0.1-1.0 \mathrm{~g} \cdot \mathrm{m}^{-3}$ ) than that of HAMSTRAD and the sondes. IASI also tends to show standard deviations much lower by $0.2-0.8 \mathrm{~g} \cdot \mathrm{m}^{-3}$ than those of HAMSTRAD and sonde data sets.

Finally, the best results (mean, standard deviation, bias, and correlation) are obtained so far when the HAMSTRAD radiometer operates in the very dry conditions of February, namely, in dryness conditions comparable to Dome C summertime values. We are thus very confident in the optimal use of HAMSTRAD when deployed at Dome C, Antarctica. We will then perform, as a validation process, the same type of analysis by comparing the HAMSTRAD vertical profiles of $\mathrm{H}_{2} \mathrm{O}$ and temperature with IASI and daily sonde measurements.

\section{ACKNOWLEDGMENT}

The authors would like to thank O. Drasin from the Laboratoire d'Aérologie for his strong implication in the analysis of the different data sets. IASI has been developed and built under the responsibility of the Centre National d'Etudes Spatiales. It is flown on board the MetOp satellites as part of the EUMETSAT Polar System. The IASI level-2 data are received through the EUMETCast near-real-time data distribution service. IASI vertical profiles of water vapor were extracted from the Ether French atmospheric database (http://ether.ipsl.jussieu.fr). Absolute humidity measured from radio soundings performed in Bordeaux, France, and in Zaragoza, Spain, was retrieved from the web site of the University of Wyoming, Laramie, at http://weather.uwyo.edu/ upperair/sounding.html.

\section{REFERENCES}

[1] M. Scherer, H. Vömel, S. Fueglistaler, S. J. Oltmans, and J. Staehelin, "Trends and variability of midlatitude stratospheric water vapor deduced from the re-evaluated Boulder balloon series and HALOE," Atmos. Chem. Phys., vol. 8, no. 5, pp. 1391-1402, Mar. 2008.

[2] E. Motte, P. Ricaud, B. Gabard, M. Niclas, and F. Gangneron, "A 22 GHz mobile microwave radiometer (MobRa) for the study of stratospheric water vapor," IEEE Trans. Geosci. Remote Sens., vol. 46, no. 10, pp. 31043114, Oct. 2008.

[3] P. Ricaud, B. Gabard, S. Derrien, J.-P. Chaboureau, T. Rose, A. Mombauer, and H. Czekala, "HAMSTRAD-Tropo, A 183-GHz radiometer dedicated to sound tropospheric water vapor over Concordia station, Antarctica," IEEE Trans. Geosci. Remote Sens., vol. 48, no. 3, pt. 2, pp. 1365-1380, Mar. 2010.

[4] P. Ricaud, B. Gabard, O. Drasin, S. Derrien, J.-P. Chaboureau, J.-L. Attié, T. Rose, A. Mombauer, and H. Czekala, "The 183-GHz HAMSTRADTropo radiometer: Validation over the Pyrenees Mountains (France) and first measurements at Dome C (Antarctica)," in Proc. IEEE IGARSS Conf., Cape Town, South Africa, Jul. 13-17, 2009. [CD-ROM].

[5] J. P. Lafore, J. Stein, N. Asencio, P. Bougeault, V. Ducrocq, J. Duron, C. Fischer, P. Hereil, P. Mascart, J. P. Pinty, J. L. Redelsperger, E. Richard, and J. Vila-Guerau de Arellano, "The Meso-NH atmospheric simulation system. Part I: Adiabatic formulation and control simulations," Ann. Geophys., vol. 16, no. 1, pp. 90-109, 1998

[6] H. J. Liebe, "MPM, an atmospheric millimeter-wave propagation model," Int. J. Infrared Millim. Waves, vol. 10, no. 6, pp. 631-650, Jun. 1989.

[7] P. W. Rosenkranz, "Water vapor microwave continuum absorption: A comparison of measurements and models," Radio Sci., vol. 33, no. 4, pp. 919-928, Jul./Aug. 1998.

[8] V. Mattioli, E. R. Westwater, D. Cimini, A. J. Gasiewski, M. Klein, and V. Y. Leuski, "Microwave and millimeter-wave radiometric and radiosonde observations in an arctic environment," J. Atmos. Ocean. Technol., vol. 25, no. 10, pp. 1768-1777, Oct. 2008.

[9] P. Ricaud, J.-L. Attié, H. Teyssèdre, L. El Amraoui, V.-H. Peuch, M. Matricardi, and P. Schluessel, "Equatorial total column of nitrous oxide as measured by IASI on MetOp-A: Implications for transport processes," Atmos. Chem. Phys., vol. 9, no. 12, pp. 3947-3956, Jun. 2009.

[10] EUMETSAT, EUM/OPS-EPS/MAN/04/0033 IASI Level 2 Products Guide, 2004. [Online]. Available: http://oiswww.eumetsat.org/WEBOPS/ eps-pg/IASI-L2/IASIL2-PG-0TOC.htm

[11] P. Schlüssel, T. H. Hultberg, P. L. Phillips, T. August, and X. Calbet, "The operational IASI level 2 processor," Adv. Space Res., vol. 36, no. 5, pp. 982-988, 2005.

[12] C. Tomasi, B. Petkov, E. Benedetti, V. Vitale, A. Pellegrini, G. Dargaud, L. De Silvestri, P. Grigioni, E. Fossat, W. L. Roth, and L. Valenziano, "Characterization of the atmospheric temperature and moisture conditions above Dome C (Antarctica) during austral summer and fall months," J. Geophys. Res., vol. 111, no. D20, p. D20305, 2006, DOI: 10.1029/2005JD006976. 